\title{
Unconscionability and Contract: The creeping shoots of Bundy
}

\author{
S. Greenfield ${ }^{\star}$ and G. Osborn ${ }^{\star \star}$
}

Whilst the Courts have long been able to set aside contracts falling within the compass of what might be termed 'categories of unconscionability', '1 it appeared after the House of Lords decision in National Westminster Bank plc v. Morgan ${ }^{2}$ that there was a marked reluctance to see these discrete areas as part of a general doctrine of unconscionability revolving around the notion of inequality of bargaining power. However, recent decisions in the field of entertainment law seem to suggest that a general principle may indeed be making a comeback via the doctrine of restraint of trade. ${ }^{3}$ Within these cases the lack of specialist advice and the inequality of bargaining power between the parties have proved crucial, and the Courts' decisions have appeared to support the notion of a general principle that was advanced by Lord Denning in Lloyds Bank v. Bundy. ${ }^{4}$

Calls for a single unifying principle are by no means of purely modern origin. In one of the earliest authorities, ${ }^{5}$ Kenyon MR stated that: "I lay great stress upon the situation of the parties to [the bargain], and the persons who compose the drama", before proceeding to note that cases involving infants and guardians:

"all proceed on the same general principle, and establish this, that if the party is in a situation in which he is not a free agent and is not equal to protecting himself, this court will protect him." 6

The underlying theme of protection of the weaker party is reflected in many cases but perhaps is best exemplified by Fry v. Lane, ${ }^{7}$ where Lord Kay, in reviewing the cases said:

* Senior Lecturer in Law, ${ }^{\star}$ Lecturer in Law, University of Westminster.

1. See, e.g., Waddams, "Unconscionability in Contracts", [1976] M.L.R. 369 or more generally, Atiyah, Rise and Fall of Freedom of Contract (1979).

2. [1985] 1 All E.R. 821.

3. See generally on the notion of restraint of trade in the entertainment industry, "Unchained Melody: Restraint of Trade and Music Contracts", [1992] B.L.R. 223.

4. [1975] Q.B. 326.

5. Evans v. Llewellin (1787) 1 Cox 334.

6. Ibid., at p. 340 .

7. (1888) 50 Ch.D. 312, All E.R. Reprints (1886-90), 1084. 
"the result of the decisions is that where a purchase is made from a poor and ignorant man at a considerable undervalue, the vendor having no independent advice, a court of equity will set aside the transaction."

The tenor of this argument was echoed by Lord Denning, then Master of the Rolls, some 90 years later when he forcefully propounded a general principle encompassing the notion of inequality of bargaining power.

Lloyds Bank v. Bundy concerned an elderly farmer who mortgaged his farmhouse to Lloyds Bank upon their insistence that without this assurance they would no longer continue to support his son's business. The Assistant Manager neglected to explain fully the position and possible ramifications of such a charge being made against the property to Mr Bundy; the son's business later collapsed and the Bank proceeded to enforce the charge and guarantee. The decision of the Court of Appeal was based on the finding that there existed a fiduciary duty between the Bank and the defendant, that there had been a conflict of interest between the Bank and Mr. Bundy and that the Bank had neglected to inform him fully of his position. Accordingly, the Bank was not allowed to retain its benefit from the transaction. Whilst the actual decision rested upon the narrow ground of undue influence, Lord Denning, having accepted that in the majority of cases a customer who signs a guarantee is unable to renege upon it, ${ }^{9}$ took the opportunity to examine those areas where Courts have set contracts aside. ${ }^{10} \mathrm{His}$ analysis rested upon the fact that having reviewed the situations where the court was prepared to enquire into a contract, these situations were in fact underpinned by a common theme:

\begin{abstract}
"Gathering all together, I would suggest that through all these instances there runs a single thread. They rest on 'inequality of bargaining power'. By virtue of it, the English law gives relief to one who, without independent advice, enters into a contract on terms which are very unfair or transfers property for a consideration which is grossly inadequate, when his bargaining power is grievously impaired by reason of his own needs or desires, or by his own ignorance or infirmity, coupled with undue influences or pressures brought to bear on him for the benefit of the other." 11
\end{abstract}

The rest of the Court were somewhat more circumspect in their analysis preferring

8. Ibid., at p. 1089 .

9. This reflects the traditional reluctance on the part of the Court to interfere in contractual negotiation: see, e.g., L'Estrange v. F. Graucob [1934] 2 K.B. 394.

10. Lord Denning cites at pp. 763-5 contracts being set aside for reason of fraud, misrepresentation or mistake and suggested that there were 5 existing areas where a court would grant relief: "Hitherto those exceptional cases have been treated each as a separate category in itself' (at p. 763). These categories were (i) duress of goods; (ii) the unconscionable transaction; (iii) undue influence; (iv) undue pressure; and (v) salvage agreements.

11. Ibid., at p. 765 . 
a narrow interpretation, although Sir Eric Sachs expressed guarded sympathy with the principle Lord Denning was espousing:

\begin{abstract}
"as regards the wider areas covered in the masterly survey in the judgment of Lord Denning MR, but not raised arguendo, I do not venture to express an opinion - though having some sympathy with the views that the courts should be able to give relief to a party who has been subject to undue pressure."12
\end{abstract}

Interestingly, the general theme of Lord Denning's analysis was concurrently receiving independent judicial support in the House of Lords. Schroeder v. Macaulay ${ }^{13}$ concerned an exclusive publishing agreement made between the parties in July 1966. In 1970 Macaulay, who at the time of signing the agreement was 21 years old, sought a declaration that the agreement made was contrary to public policy and void. The declaration was granted by Plowman $J$ at first instance and confirmed by the Court of Appeal. In the House of Lords it was left to Lord Reid to state that:

"The law with regard to the validity of agreements in restraint of trade was fully considered by this house [in Esso] ${ }^{14}$ and I do not intend to restate the principles there set out or to add to or modify what I said myself. I think that in a case like the present case two questions must be considered. Are the terms of the agreement so restrictive that either they cannot be justified at all or they must be justified by the party seeking to enforce the agreement? Then, if there is room for justification, has that party proved justification normally by shewing that the restrictions were no more than what was reasonably required to protect his legitimate interests."15

The agreement itself contained seventeen clauses; the crucial terms relating to the restraint argument were, inter alia, that:

a) the agreement was to last for a period of 5 years in the first instance but this was to be extended by another 5 years if the royalties for the first period exceeded $£ 5000$. The royalty sum was in fact minimal and in effect the duration was to all intents and purposes ten years. As Lord Reid noted:

"The duration of an agreement in restraint of trade is a factor of great importance in determining whether the restrictions in the agreement can be justified ..."16

12. Ibid., at p. 771 .

13. [1974] 3 All E.R. 616.

14. Esso Petroleum Co. v. Harpers Garage Southport [1968] A.C. 269.

15. Supra n. 13, at p. 618.

16. Ibid., at p. 621 . 
b) The songwriter was bound exclusively to the Publisher for this period.

c) The publishers retained the right to terminate the agreement on notice. Crucially there was no similar right vested in the songwriter.

Lord Reid also refused to read into the contract an agreement to act in good faith by the appellants; the importance of this being that there was no obligation stated in the agreement actually to exploit or publish the works in the artist's best interests. If the publisher chose not to publish the works, the songwriter was prevented from plying his trade and his creative output was effectively sterilised.

Looking at the agreement as a whole, Lord Reid held that the agreement was, on its face, unduly restrictive and that the appellants had not succeeded in justifying such terms. The argument of Lord Diplock is illuminating in that whilst he reached the same conclusion, his line of reasoning concentrated on the notion of 'fairness' and that:

"what your Lordships have in fact been doing has been to assess the relative bargaining power of the publisher and the songwriter at the time the contract was made and to decide whether the publisher had used his superior bargaining power to exact from the songwriter promises that were unfairly onerous to him."'17

The affinity with Denning's general approach was further evidenced by his description of the principle that underpinned the doctrine of restraint of trade:

"the public policy which the court is implementing is not some 19th century economic theory about the benefit to the general public of freedom of trade, but the protection of those whose bargaining power is weak against being forced by those whose bargaining power is stronger to enter into bargains that are unconscionable."18

With the dust scarcely settled in Schroeder, Lord Denning returned to the subject in Clifford Davis v. WEA Records. ${ }^{19} \mathrm{He}$ drew comfort from the speeches of Lords Diplock and Reid, ${ }^{20}$ and argued that both had supported his approach in Bundy:

"Reading those speeches in the House of Lords, they afford support for the principles we endeavoured to state at the end of last term about inequality of bargaining power."21

17. Ibid., at p. 623 .

18. Ibid..

19. [1975] 1 All E.R. 237.

20. In Schroeder.

21. Clifford Davis, at p. 240. 
Denning addressed the issue of common fairness in preventing the strong pushing the weak to the wall. He also raised the related issue of independent legal advice:

"The composer had no lawyer and no legal advisers. It seems to me that, if the publisher wished to exact such onerous terms or to drive so unconscionable a bargain, he ought to have seen that the composer had independent advice."22

A cursory examination at this point might well lead to the conclusion that Lord Denning's approach was, with the support of the House of Lords, becoming entrenched despite its relatively short gestation period. However, whilst the three cases cited above had all stressed the importance of the doctrine of inequality of bargaining power, the House of Lords returned to a more traditional analysis in National Westminster Bank v. Morgan.

As with Bundy, the substantive issue was undue influence. Lord Scarman in delivering the court's judgment, upheld the Bank's contention that there had been no dominating influence exerted upon Mrs. Morgan and that the transaction itself was not unfair to her. Having allowed the appeal, Lord Scarman went on to consider the vexed question of whether the Court of Appeal in Bundy had accurately stated the law.

Having first approved Sir Eric Sachs narrow interpretation, ${ }^{23}$ he turned to consider Denning's argument in favour of the notion of 'inequality of bargaining power':

"The fact of an unequal bargain will of course be a relevant feature in some cases of undue influence. But it can never become an appropriate basis of principle of an equitable doctrine which is concerned with transactions ' $n o t$ to be reasonably accounted for on the ground of friendship, relationship, charity, or other ordinary motives on which ordinary men act' (per Lindley $\mathrm{J}$ in Allcard $)$... And even in the field of contract I question whether there is any need in the modern law to erect a general principle of relief against inequality of bargaining power." 24

Lord Scarman's approach was, as Enman notes, consistent with English courts seeking refuge in laissez faire notions of freedom of contract. ${ }^{25}$ However, recent cases following the line of Schroeder and Clifford Davis, suggest that any writing off of the doctrine may yet prove to be premature.

22. Ibid., at p. 241 .

23. This narrow analysis followed the reasoning of Allcard v. Skinner (1887) $36 \mathrm{Ch} .145$.

24. National Westminster v. Morgan, at p. 830.

25. Enman, "Doctrines of Unconscionability in England, Canada and the Commonwealth", [1987] Anglo-American Law Rev. at p. 202. 


\section{The recent music cases}

The points raised by Schroeder resurfaced in the Court of Appeal in ZTT Records and Another v. Holly fohnson. ${ }^{26}$ Here there was both a publishing and recording agreement at stake. The issue for the court was whether the agreements signed by the respondent were unenforceable as an unreasonable restraint of trade. The case concerned agreements made in 1983 and 1984 between the members of the band 'Frankie goes to Hollywood' and the directors of ZTT Records and Perfect Songs Publishing Ltd., the directors and shareholders in both of these being Trevor Horn and Jill Sinclair.

The contract provided that the band was, in the first instance, to be bound to the two companies, both individually and collectively, for a period of seven months (Clause 3). However, the clause itself reserved the right of the Company to exercise a series of options; Clause 3.2 providing that

"[the] artist irrevocably grants to [the] company options to extend the term of this agreement for 2 separate and successive option periods and 5 separate and successive contract periods."

The periods themselves were to be the longer of 12 calendar months or 120 days after the delivery of the minimum recording commitment. ${ }^{27}$ Thus whilst on the face of it the term was 7 months, by exercising the option periods under the contract the band could be tied to the Company for a period of 8 to 9 years.

Further to this the contract provided that if any new member was to join the band he or she would be deemed to be bound by the terms of the agreement; and that if any member chose to leave the band the company reserved the right to contract that individual into a separate agreement on the same terms and conditions as the first agreement.

The duration of the term and the provisions relating to new and leaving members were sufficient for Dillon $\mathrm{LJ}$ to find that "the recording agreement as a whole is unenforceable because it is an unreasonable restraint of trade."28 However, whilst the analysis of the case can be based on a logical extension of the doctrine of restraint of trade from the publishing agreements of Schroeder and into the lucrative area of recording agreements, Dillon LJ's arguments owe much to the reasoning of Lord Diplock in the same case. As was noted above, Lord Diplock based his analysis of the situation in Schroeder on whether the contract was fair. There was no evidence of undue influence on the part of Horn or Sinclair in the present case but, as Dillon LJ put it:

26. Independent Law Reports, 2 August 1989.

27. The minimum recording commitments and option periods are specified in Clause 4.1.

28. Court of Appeal Transcript, 26 July 1989, at p. 12. 
"What is said is that the terms of the recording agreement and publishing agreement put forward by the recording company and the publishing company, even after such concessions as were made during the negotiations, were so one sided and unfair that consistently with the principles applied by the House of Lords [in Schroeder] they cannot stand and cannot be enforced against the defendant."29

Thus whilst the case can be confined to the strict restraint of trade argument, the reasoning employed by Dillon $\mathrm{LJ}$ relies to a great extent on the notion of inequality of bargaining power alluded to by Lord Diplock and championed by Lord Denning in Bundy. Also noted within the decision are the relative positions of the parties; the importance of this was emphasised by the High Court in an unreported case concerning 'The Stone Roses'. ${ }^{30}$

'The Stone Roses' case concerned both a recording and publishing agreement made between the parties in April 1988. In finding that the agreement was indeed unenforceable as an unreasonable restraint of trade, Judge Humphries found certain terms to be crucial.

\section{i) Duration}

The band was tied to the Companies for a minimum of 7 years. However, by the operation of an alternative option calculation the term would, if later, expire 9 months after the release of the minimum recording required in the United States. There was no obligation to release any of the band's material in the U.S. and the band could have been tied to the label indefinitely.

\section{ii) Exclusivity}

By clause 4 of the agreement, Zomba had the exclusive and sole right to exploit the Stone Roses' recordings. The decision as to the reproduction, distribution or release of the product rested solely with Zomba. The band was also forbidden to render any performances where there existed a possibility of recording and future manufacture and release.

iii) Territory

As the Judge noted, 'the world and its solar system' could hardly have been more extensive.

Whilst those terms in particular and the agreement as a whole led to a finding of an unreasonable restraint of trade, Judge Humphries comments regarding the relative bargaining powers make interesting reading. The solicitor used by the manager of The Stone Roses was Geoffrey Howard, about whom Judge Humphries said:

29. Ibid., at p. 3 .

30. Silvertone Records v. Mountfield \& Ors, Zomba Music v. Mountfield \& Ors (unreported) 20 May 1991. 
"Mr. Howard may well be and may well have been competent in many parts of a solicitor's work, but he was not, and nor did Mr. Evans or the plaintiffs ever believe him to be, an experienced music lawyer." 31

Having described Mr. Furman, the plaintiff's lawyer, as an experienced barrister with considerable expertise in the field of music contracts, he went on to describe the wider role of the music lawyer:

"... the services of a music lawyer in contracts such as the one in consideration is not as in many contracts simply to explain the legal meaning to clients and to ensure where appropriate that the contract is representing what the client wants. Within the entertainment industry, or at any rate the subject I am considering, music lawyers go much further. They need the expertise to appreciate many of the terms, something of the state of the market, the state of the law on restraint and entertainment contracts, which in recent years has been developing rapidly. Music lawyers habitually get involved in negotiations and know where it is right to and where they are able to put pressure on the other side so as to thrash out an agreement which is fair to both sides. Mr. Howard had none of this expertise. He had I doubt ever heard of the Holly fohnson case and I am sure he had no appreciation whatever what it was all about, and am quite satisfied he was no match whatever for the expertise and experience on the plaintiff's side." ${ }^{32}$

Whilst this case too withstands a strict analysis in terms of restraint of trade, the reasoning again rests on the relative bargaining power of the parties. Had the plaintiffs recommended that $\mathrm{Mr}$. Evans seek specialist independent advice before signing the contract the outcome may well have been significantly different. As it was, the plaintiff's superiors themselves on hearing of the terms of the agreement that had been signed expressed concern that the lack of substantial negotiation could render the contract unenforceable.

\section{Conclusion}

The immediate ramifications of these decisions on the music and entertainment industries seems uncontroversial; contracts made without recourse to specialist independent advice which contain unduly restrictive terms may be subject to legal scrutiny. The Music Industry will no doubt take heed of these warnings and conduct their negotiations accordingly. Whether this heralds a resurrection of a general principle of unconscionability, based on inequality of bargaining power, appears to be more problematic.

31. Transcript of the High Court, Queen's Bench Division, 20 May 1991, at p. 33.

32. Ibid., at pp. 33-34. 
Certainly the courts appear to be considering the fairness of contracts and the circumstances surrounding the making of such a contract, but this must be seen against the enmity exhibited by Lord Scarman towards a general principle. What does seem apparent is that whilst the development of Lord Denning's principle may have been headed off in a limited range of cases through the Morgan decision, the seeds sown by Lord Diplock in Schroeder and Lord Denning in Clifford Davis have found fertile ground within the doctrine of restraint of trade and may prove far more difficult to suppress. 